\title{
Effect of L-carnitine on postischemic inhibition of protein synthesis in the rat brain
}

\author{
Jozef Burda ${ }^{1}$, Mariluz Hernández Viadel $^{2}$, Viera Danielisová ${ }^{1}$, Miroslava Némethová1, \\ Carmina Montoliu ${ }^{2}$ and Vicente Felipo ${ }^{2}$ \\ ${ }^{1}$ Institute of Neurobiology, Slovak Academy of Sciences, Košice, Slovakia \\ ${ }^{2}$ Instituto de Investigaciones Cytologicas, Fundación Valenciana de Investigaciones Biomédicas, Valencia, Spain
}

\begin{abstract}
The purpose of this study was to investigate effects of carnitine administration on protein synthesis recovery after transient cerebral ischemia. Rats received L-carnitine in two doses of $16 \mathrm{mmol} / \mathrm{kg}$ i.p. $15 \mathrm{~min}$ before ischemia and just on the onset of reperfusion. Transient forebrain ischemia was induced by 4 -vessel occlusion for $15 \mathrm{~min}$, followed by $30 \mathrm{~min}$ or 7 days of reperfusion. Protein synthesis rate, reinitiation ability and neurodegeneration in the frontal cortex and hippocampus were measured by the incorporation of radioactively labelled leucine into polypeptide chains in postmitochondrial supernatants and by Fluoro-Jade B staining.

A protective effect was observed, on protein synthesis as well as the number of surviving neurons, in the L-carnitine-treated groups. Our results indicate that L-carnitine can exert a protective effect in the development of reperfusion-induced injury. L-carnitine significantly reduced the ischemia/reperfusion-induced inhibition of translation and neurodegeneration in the neocortex as well as in the highly sensitive hippocampus and dorsolateral striatum. We expect that the ability of L-carnitine to keep translational machinery on facilitates efficacy of postischemic remodulation of gene expression.
\end{abstract}

Key words: Ischemia — Protein synthesis - L-carnitine - Hippocampus

\section{Introduction}

Carnitine (3-hydroxy-4-N-trimethylammonium-butyrate), widely distributed in the body including the nervous system, is an essential cofactor for $\beta$-oxidation of fatty acids in the mitochondria (Evans and Fornasini 2003; Limketkai and Zucker 2008). Free L-carnitine is found in many foods, mainly those from animal sources. L-carnitine administration reduces oxidative stress (Tunez et al. 2007; Tsakiris et al. 2008). It is well documented that, in the brain, L-carnitine is a potent protector against ischemia (Matsuoka and Igisu 1992), hypoxia (Koudelova et al. 1994; Kuzin and Kolesnikova 1999), glutamate toxicity in animals (Felipo et al. 1994a,b) as well as cell cultures (Minana et al. 1996; Felipo et al. 1998). L-carnitine plays an integral role in attenuating brain injury associated with mitochondrial neurodegenerative disorders

Correspondence to: Jozef Burda, Institute of Neurobiology, Slovak Academy of Sciences, Šoltésovej 4, 04001 Košice, Slovakia E-mail: burda@saske.sk
(Wang et al. 2007) and effectively blocks neuronal apoptosis caused by inhalation anesthetics in the developing rat brain (Zou et al. 2008).

Protein synthesis requires a number of precise steps as well as activity of many enzymes and because of its complexity; it is extremely sensitive to changes of cell energy charge and ionic concentrations. Although ischemia per se produces relatively moderate changes which are dependent on the model and duration of ischemia and intraischemic temperature, it generates background for profound protein synthesis alterations occurring during subsequent reperfusion (Burda et al. 1998). First minutes of postischemic reperfusion are characterised by a nearly complete block of translation, due mainly to the inhibition of initiation, which is manifested by disaggregation of polyribosomes to monosomes and ribosomal subunits (Kleihues et al. 1975; Cooper et al. 1977; Burda et al. 1980). After brainwide transient inhibition of initiation, most brain regions recover their protein synthesis capability; however, in the selectively vulnerable regions, the inhibition of protein 
synthesis is persistent (Thilmann et al. 1986; Widmann et al. 1991; Kato et al. 1995). Deep inhibition of translation occurring immediately after restoration of blood flow to ischemic brain tissue seems to be caused mainly by phosphorylation of the a subunit ( $38 \mathrm{kDa}$ ) of eukaryotic initiation factor 2 (eIF-2) (Burda et al. 1994; DeGracia et al. 1996). The impact of this translational inhibition lies in the fact that this inhibition is practically irreversible in the selectively vulnerable neuronal populations of the brain (Thilmann et al. 1986; Widmann et al. 1991). This means that, in these neuronal populations, protein synthesis remains inhibited until the delayed death of neurons occurring three days after the ischemic attack.

In our experiment we tried to utilize antioxidant abilities of L-carnitine to support our previous results indicating that acute postischemic inhibition of protein synthesis is caused by a burst of free oxygen radical production during the first minutes of reperfusion.

\section{Materials and Methods}

\section{Experimental model}

Incomplete forebrain ischemia was induced in adult Wistar rats (mean body weight $300 \mathrm{~g}$ ) by the standard four-vessel occlusion model of Pulsinelli and Brierley (1979) as modified by Schmidt-Kastner et al. (1989). EEG as well as neurological investigation (righting and pupilar reflex) was performed to verify ischemia severity. The Ethics Committee at the Institute of Neurobiology of Košice, and the State Veterinary and Alimentary Administration of the Slovak Republic approved the experiments. Briefly, on day 1 both vertebral arteries were irreversibly occluded by coagulation through the alar foramina after anaesthesia with ketamine and xylazine (100 and $15 \mathrm{mg}$ i.p. per $\mathrm{kg}$ of body weight, respectively). On day 2, both common carotid arteries were occluded by means of small atraumatic clips under anaesthesia with $2.5 \%$ halothane. Two minutes before carotid-occlusion, halothane was removed from the mixture. A microthermistor placed deep in the ear monitored normothermic conditions $\left(37^{\circ} \mathrm{C}\right)$ maintained with a homeothermic blanket. Rats underwent $15-\mathrm{min}$ ischemia followed by $30 \mathrm{~min}(n=5$ in each group) or 7 days of reperfusion ( $n=5$ in each group). Criteria indicating correct ischemia were: loss of the righting reflex, mydriasis, paw extension, and isoelectric line on EEG, if monitored. The rats that became unresponsive and lost the righting reflex during bilateral carotid artery occlusion and showed no seizures during and after ischemia were used for the experiment. Sham control animals were prepared in the same way without carotid occlusion $(n=5)$.
L-carnitine was administrated in two doses (both 16 $\mathrm{mmol} / \mathrm{kg}$ i.p.), the first $15 \mathrm{~min}$ before ischemia and the second just at the onset of reperfusion.

\section{Preparation of tissue fractions}

Fresh neocortex and hippocampus obtained under the different experimental conditions were dissected and homogenised $1: 2(\mathrm{w} / \mathrm{v})$ with buffer $\mathrm{H}(50 \mathrm{mmol} / \mathrm{l}$ Hepes-KOH, $\mathrm{pH}$ $7.55 ; 140 \mathrm{mmol} / \mathrm{l}$ potassium acetate; $4 \mathrm{mmol} / \mathrm{l}$ magnesium acetate; $2.5 \mathrm{mmol} / \mathrm{l}$ dithiothreitol; $0.32 \mathrm{~mol} / \mathrm{l}$ sucrose). The postmitochondrial supernatant (PMS) was obtained by centrifugation of homogenate at $11,000 \times g$ for $15 \mathrm{~min}$ at $4^{\circ} \mathrm{C}$ and kept at $-70^{\circ} \mathrm{C}$ until used.

\section{In vitro translation}

In vitro translation was assessed in a cell-free system as previously reported (Burda et al. 1994). The complete reaction system in a final volume of $50 \mu \mathrm{l}$ contained: $50 \mathrm{mmol} / \mathrm{l}$ Hepes- $\mathrm{KOH}, \mathrm{pH} 7.55 ; 140 \mathrm{mmol} / \mathrm{l}$ potassium acetate; $4 \mathrm{mmol} / \mathrm{l}$ magnesium acetate; $2.5 \mathrm{mmol} / \mathrm{l}$ dithiothreitol; 0.32 mol/l sucrose; $1 \mathrm{mmol} / \mathrm{l} \mathrm{ATP} ; 0.75 \mathrm{mmol} / \mathrm{l} \mathrm{GTP} ; 20 \mathrm{mmol} / 1$ phosphocreatine; $150 \mu \mathrm{g} / \mathrm{ml}$ creatine phosphokinase; 50 $\mu \mathrm{mol} / \mathrm{l}$ amino acids, $100 \mu \mathrm{g}$ of PMS proteins and $0.3 \mu \mathrm{Ci}$ of $\left[{ }^{14} \mathrm{C}\right]$-leucine $(8.88 \mathrm{GBq} / \mathrm{mmol})$. After 45 -min incubation at $30^{\circ} \mathrm{C}, 50 \mu \mathrm{l}$ samples (triplicate) were used to measure the radioactivity present in $10 \%$ trichloroacetic acid insoluble material. Reinitiation ability was calculated as a difference between total leucine incorporated and value of elongation obtained by incubation of samples in the presence of initiation inhibitor - aurintricarboxylic acid $(60 \mu \mathrm{mol} / \mathrm{l})$.

\section{Histology}

For histological analysis, after recirculation periods, the rats were deeply anesthetized by chloralhydrate $(300 \mathrm{mg}$ per $\mathrm{kg}$ of body weight) and perfused transcardially with saline followed by freshly prepared $4 \%$ paraformaldehyde in $0.1 \mathrm{~mol} / \mathrm{l}$ phosphate buffer, $\mathrm{pH}$ 7.4. Following perfusion fixation, the brain was carefully dissected out and stored in same fixative for $3 \mathrm{~h}$ at $4^{\circ} \mathrm{C}$. After postfixation, the brains were cut on a vibratome at $30 \mu \mathrm{m}$ and the sections were mounted onto gelatin-coated slides an air-dried overnight. To examine histological changes in neurons, Fluoro-Jade B and cresyl-violet staining was performed. The slides were coverslipped with DPX. Quantification of neurodegeneration was performed from digital microphotographs taken by an Olympus BX 51 microscope. The Fluoro-Jade B positive cells were counted in the middle of the linear part of hippocampal CA1 region $(-3.3 \pm 0.2 \mathrm{~mm}$ posterior of the bregma) in each animal and expressed as the average of 10 measurements of positive pyramidal neurons per 


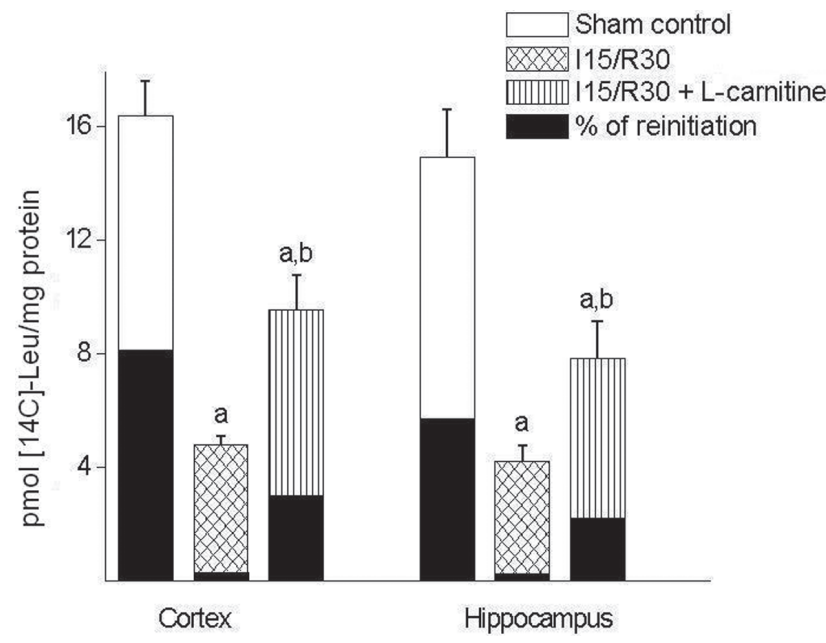

Figure 1. Incorporation of labelled leucine $\left(\left[{ }^{14} \mathrm{C}\right]-\mathrm{Leu}\right)$ into polypeptide chains in cell-free system from cortex and hippocampus of rats after $15 \mathrm{~min}$ of ischemia (I15) and subsequent $30 \mathrm{~min}$ of reperfusion (R30) with and without L-carnitine administration. Expressed as pmol of leucine/mg of PMS proteins \pm S.E.M. ${ }^{a}$ significant difference in comparison to sham control group ( $p<$ $0.05) ;{ }^{b}$ significant difference in comparison to L-carnitine-treated group $(p<0.05)$.

$1 \mathrm{~mm}$ of the linear part of the CA1 region and $1 \mathrm{~mm}^{2}$ if degenerated neurons were counted in the cortex.

\section{Statistical evaluation}

Statistical analysis of the differences between sham control animals and animals with L-carnitine was performed using ANOVA followed by Dunnet's test.

\section{Results}

Protein synthesis rate measured in vitro in brain extracts (Fig. 1) clearly demonstrated known protein synthesis inhibition, which appears $30 \mathrm{~min}$ after $15 \mathrm{~min}$ of ischemia. Without L-carnitine administration, these experimental conditions lead to $77.7 \%$ inhibition of total protein synthesis with $2 \%$ reinitiation ability in the cortex, and $71.6 \%$ inhibition of total protein synthesis with $1.9 \%$ reinitiation ability in the hippocampus. With L-carnitine values of protein synthesis inhibition represent only 41.8 and $47.3 \%$ for cortex and hippocampus, respectively (both significantly improved, $p<$ 0.05 ). The positive effect of $\mathrm{L}$-carnitine is even more obvious in the case of reinitiation capability which is improved to 18.3 and $14.9 \%$ in cortex and hippocampus, respectively.

The protective effect of L-carnitine, significantly reducing postischemic inhibition of protein synthesis, leads to an increased number of surviving neurons in both monitored brain regions including the selectively vulnerable hippocampal CA1 after 7 days of reperfusion. Fig. 2 is a representative microphotograph of the hippocampus. Quantification of degenerating neurons in the centre of the linear part of the CA1 region visualised by Fluoro-Jade B staining shows a significant $(p<0.05)$ difference between groups with and without L-carnitine administration. The number of degenerating CA1 neurons after $15 \mathrm{~min}$ of ischemia without L-carnitine is $296.14 \pm 21.58$ cells $/ \mathrm{mm}$ (Fig. 2A and C) while in the group with L-carnitine (Fig. 2B and $\mathrm{D})$ it is $77.50 \pm 30.89$ cells $/ \mathrm{mm}(p<0.01)$. Similarly in the cortex, the administration of L-carnitine reduced the count of degenerating neurons from $179.50 \pm 24.51 \mathrm{cells} / \mathrm{mm}^{2}$ (Fig. $3 \mathrm{~A}$ ) in the group without treatment to $50.07 \pm 23.70$ neurons $/ \mathrm{mm}^{2}$ (Fig. 3B, $p<0.01$ ) in the L-carnitine-treated group. While the area of dorsolateral striatum affected by neurodegeneration represents $3.53 \pm 0.75 \mathrm{~mm}^{2}$ in the nontreated group (Fig. 3C), L-carnitine administration (Fig. 3D) reduced this area to $0.09 \pm 0.08 \mathrm{~mm}^{2}(p<0.01)$.

\section{Discussion}

L-carnitine administration prevents the increase in thiobarbituric acid-reactive substances (index of lipid peroxidation and free radical damage) induced by 30 min hypobaric hypoxia in the rat brain (Koudelova et al. 1994). Our previous data documented that postischemic (four-vessel occlusion) changes in translation in vitro can be improved in the presence of an antioxidant in the first minutes of reperfusion (Burda and Némethová 1999; Hrehorovská et al. 2004). A method of controlled postischemic reoxygenation used to prevent or decrease the formation of free oxygen radicals resulted in significant amelioration of the postischemic inhibition of protein synthesis (Burda et al. 1991). The same effects resulted from short postischemic hypoperfusion (Burda et al. 1995) and free oxygen radical scavenger stobadine administration (Burda and Némethová 1999).

Only a few experiments have been carried out with the intention of influencing postischemic protein synthesis by therapeutic intervention. Thilmann and co-workers (1988) used cycloheximide to prevent the synthesis of proteins, which are selectively expressed during the early postischemic recirculation period and which may trigger the pathological process leading to irreversible injury. As a result, protein synthesis uniformly recovered and morphological lesions were absent. However, this effect could have been caused by the temperature drop which is induced by the drug, and it cannot be excluded that ischemic injury did not reach the threshold of neuronal vulnerability (Hossmann and Paschen 1992). In the other study gerbils were treated after 5 min of global ischemia with barbiturates, which previously have 


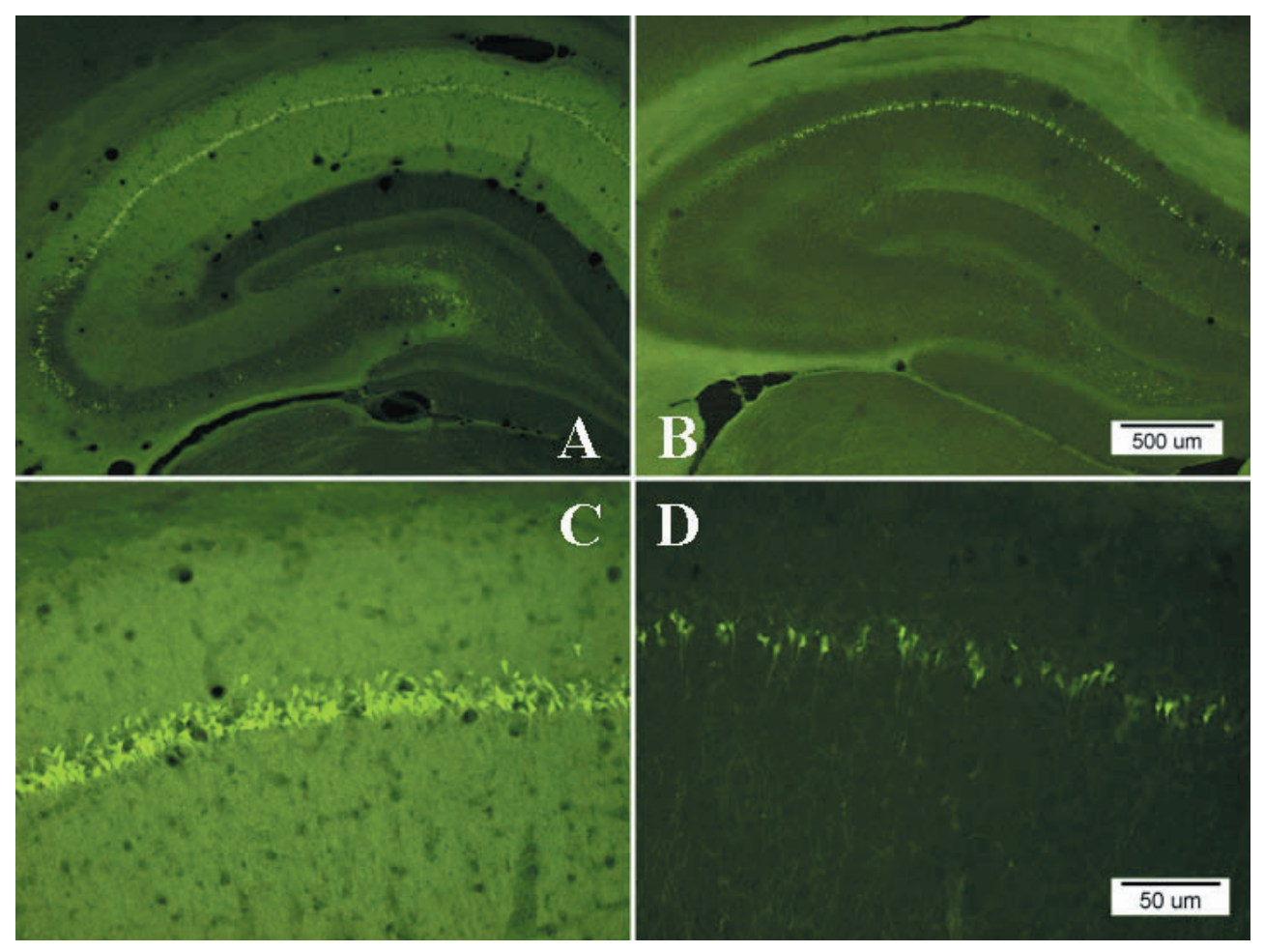

Figure 2. Ischemia and reperfusion-induced neurodegeneration of hippocampal neurons, visualized by Fluoro-Jade B fluorescence staining 7 days after 15 min of ischemia without (A and C) and with (B and D) L-carnitine. Magnification $\times 40(A, B)$ and $\times 400(C, D)$.

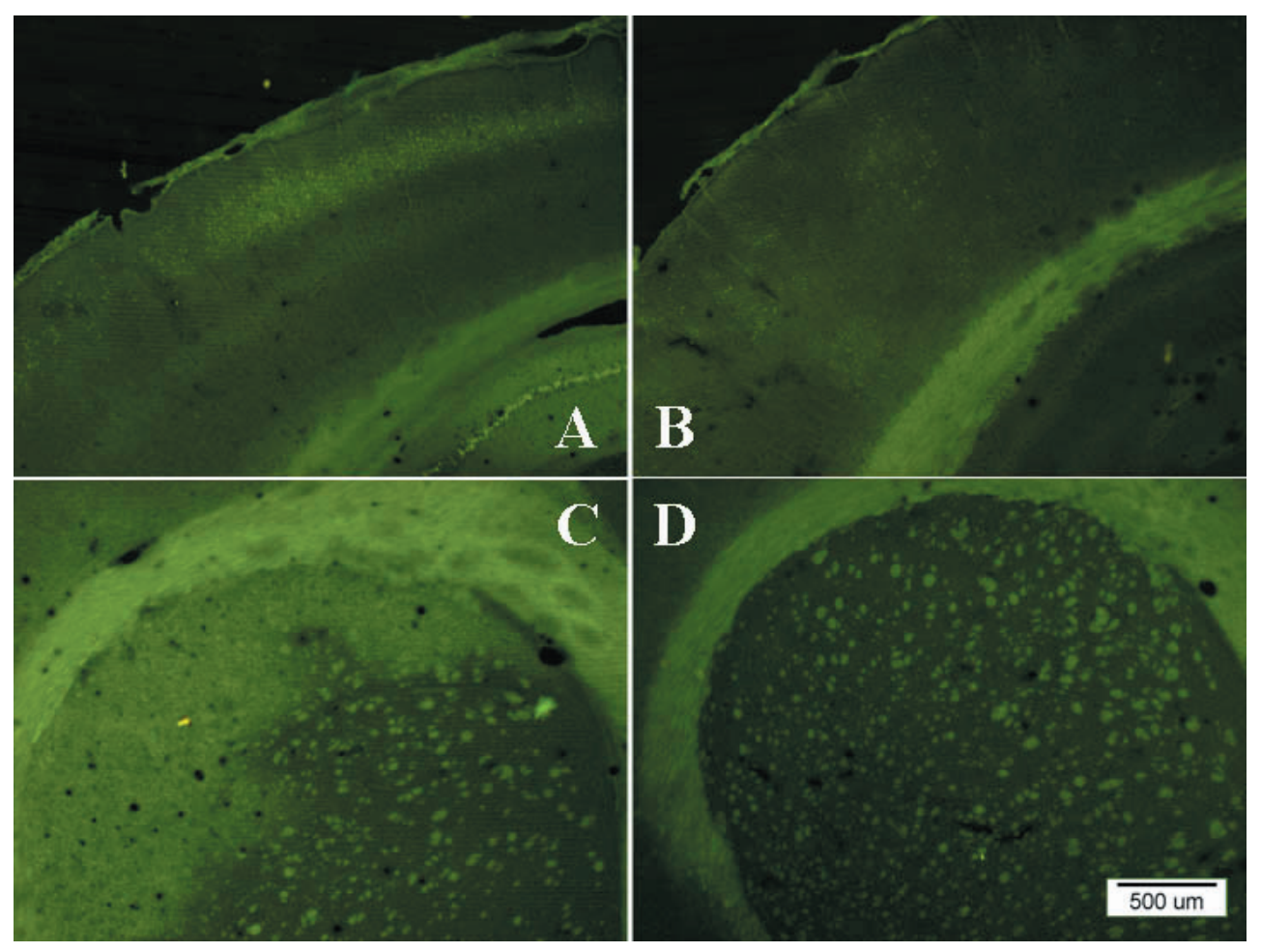

Figure 3. Ischemia and reperfusion-induced neurodegeneration of neurons in parietal cortex $(A, B)$ and striatum $(C, D)$ visualized by Fluoro-Jade B fluorescence 7 days after 15 min of ischemia without (A and C) and with (B and D) L-carnitine. Magnification $\times 40$. 
been shown to prevent morphological lesion in hippocampal CA1 sector (Hallmayer et al. 1985). As a result, hippocampal protein synthesis was normal after two days of recirculation. Two hours after ischemia, however, the inhibition of protein synthesis was equal to or even more pronounced than in untreated animals. Barbiturate therapy, in summary, promoted the recovery of protein synthesis but did not prevent the initial postischemic disturbance (Hossmann and Paschen 1992).

The main reason for postischemic translation inhibition is the a subunit phosphorylation of initiation factor eIF-2 (Burda et al. 1994). Phosphorylation is caused by a transient decrease in activity of protein phosphatases PP-1 and PP-2B (Martin de la Vega et al. 2001) as well as activation of initiation factor $2 a$ kinase (PERK) (Kumar et al. 2001).

Another known mechanism affecting postischemic protein synthesis mainly by degradation of initiation factors $4 \mathrm{E}$ and $4 \mathrm{G}$ is activation of calpain(s) (Neumar et al. 1995, 1996, 1998; Zalewska et al. 1998; Lipton 1999; White et al. 2000; DeGracia et al. 2002; Kumar et al. 2003). L-carnitine, which protects rats against glutamate toxicity, also prevented MAP-2 degradation by cytosolic $\mathrm{Ca}^{2+}$-dependent protease, which has been identified tentatively as calpain I (Felipo et al. 1993).

Kuzin and Kolesnikova (1999) found that L-carnitine after cerebral hypoxia inhibits development of apoptosis, limits the area of damage and restores structure of nervous tissue. In our study, L-carnitine significantly prevented neurodegeneration in the most sensitive brain regions such as the selectively vulnerable CA1 field of hippocampus as well as the dorsolateral striatum.

Mechanisms allowing neurons to survive, obviously including remodulation of gene expression, are still not clear. Postischemic changes including massive remodulation of gene expression (Kogure and Kato 1993; Honkaniemi et al. 1996; Yakubov et al. 2004) cannot be effective if nearly complete inhibition of protein synthesis persists in the selectively vulnerable regions (Bodsch et al. 1986; Thilmann et al. 1986). L-carnitine, by its ability to protect translational machinery permits the newly synthesized $m R N A s$ to be translated into functional proteins, thus allowing the altered gene expression to be effective. However, the prevention of inhibition of translation does not assure survival of CA1 neurons (Burda et al. 2003). But endogenous defense mechanism known as ischemic tolerance inevitably needs recovery of protein synthesis (Burda et al. 2005, 2006).

Acknowledgements. This study was supported by the grants SR: VEGA 2/0141/09 and APVV LPP 0235-06.

\section{References}

Bodsch W., Barbier A., Oehmichen M., Grosse Ophoff B., Hossmann K. A. (1986): Recovery of monkey brain after pro- longed ischemia. II. Protein synthesis and morphological alterations. J. Cereb. Blood Flow Metab. 6, 22-33

Burda J., Chavko M., Maršala J. (1980): Changes in polysomes from ischemic spinal cord. Collect. Czech. Chem. Commun. 45, 2566-2571

Burda J., Maršala M., Radoňák J., Maršala J. (1991): Graded postischemic reoxygenation ameliorates inhibition of cerebral cortical protein synthesis in dogs. J. Cereb. Blood Flow Metab. 11, 1001-1006

Burda J., Martin M. E., Garcia A., Alcazar A., Fando J. L., Salinas M. (1994): Phosphorylation of the a subunit of initiation factor 2 correlates with the inhibition of translation following transient cerebral ischaemia in the rat. Biochem. J. 302, 335-338

Burda J., Gottlieb M., Vanický I., Chavko M., Maršala J. (1995): Short-term postischemic hypoperfusion improves recovery of protein synthesis in the rat brain cortex. Mol. Chem. Neuropathol. 25, 189-198; doi:10.1007/BF02960912

Burda J., Martin M. E., Gottlieb M., Chavko M., Marsala J., Alcazar A., Pavon M., Fando J. L., Salinas M. (1998): The intraischemic and early reperfusion changes of protein synthesis in the rat brain. Eif- $2 \alpha$ kinase activity and role of initiation factors eif- $2 \alpha$ and eif-4e. J. Cereb. Blood Flow Metab. 18, 59-66; doi:10.1097/00004647-199801000-00006

Burda J., Némethová M. (1999): Effect of stobadine on the inhibition of translation induced by ischemia and subsequent reperfusion in the rat brain. Biologia (Bratislava) 54, 103-108

Burda J., Hrehorovská M., Bonilla L. G., Danielisová V., Čížková D., Burda R., Némethová M., Fando J. L., Salinas M. (2003): Role of protein synthesis in the ischemic tolerance acquisition induced by transient forebrain ischemia in the rat. Neurochem. Res. 28, 1213-1219; doi:10.1023/ A:1024232513106

Burda J., Matiasova M., Gottlieb M., Danielisova V., Nemethova M., Garcia L., Salinas M., Burda R. (2005): Evidence for a role of second pathophysiological stress in prevention of delayed neuronal death in the hippocampal cal region. Neurochem. Res. 30, 1397-1405; doi:10.1007/s11064005-8510-Z

Burda J., Danielisová V., Némethová M., Gottlieb M., Matiasová M., Domoráková I., Mechirová E., Feriková M., Salinas M., Burda R. (2006): Delayed postconditionig initiates additive mechanism necessary for survival of selectively vulnerable neurons after transient ischemia in rat brain. Cell. Mol. Neurobiol. 26, 1141-1151; doi:10.1007/s10571006-9036-x

Cooper H. K., Zalewska T., Kawakami S., Hossmann K. A., Kleihues P. (1977): Delayed inhibition of protein synthesis during recirculation after compression ischemia of the rat brain. Acta Neurol. Scand. Suppl. 64, 130-131

DeGracia D. J., Neumar R. W., White B. C., Krause G. S. (1996): Global brain ischemia and reperfusion: modifications in eukaryotic initiation factors associated with inhibition of translation initiation. J. Neurochem. 67, 2005-2012

DeGracia D. J., Kumar R., Owen C. R., Krause G. S., White B. C. (2002): Molecular pathways of protein synthesis inhibition during brain reperfusion: implications for neuro- 
nal survival or death. J. Cereb. Blood Flow Metab. 22, 127-141; doi:10.1097/00004647-200202000-00001

Evans A., Fornasini G. (2003): Pharmacokinetics of L-Carnitine. Clin. Pharmacokinet. 42, 941-967; doi:10.2165/00003088200342110-00002

Felipo V., Grau E., Minana M. D., Grisolia S. (1993): Ammonium injection induces an $\mathrm{N}$-methyl-D-aspartate receptor-mediated proteolysis of the microtubule-associated protein MAP-2. J. Neurochem. 60, 1626-1630; doi:10.1111/ j.1471-4159.1993.tb13384.x

Felipo V., Kosenko E., Minana M. D., Marcaida G., Grisolia S. (1994a): Molecular mechanism of acute ammonia toxicity and of its prevention by L-carnitine. Adv. Exp. Med. Biol. 368, 65-77

Felipo V., Minana M. D., Cabedo H., Grisolia S. (1994b): L-carnitine increases the affinity of glutamate for quisqualate receptors and prevents glutamate neurotoxicity. Neurochem. Res. 19, 373-377; doi:10.1007/BF00971588

Felipo V., Hermenegildo C., Montoliu C., Llansola M., Minana M. D. (1998): Neurotoxicity of ammonia and glutamate: molecular mechanisms and prevention. Neurotoxicology 19, 675-681

Hallmayer J. F., Hossmann K. A., Mies G. (1985): Low dose of barbiturates for prevention of hippocampal lesions after brief ischemic episodes. Acta Neuropathol. (Berl.) 68, 27-31; doi:10.1007/BF00688952

Honkaniemi J., Massa S. M., Breckinridge M., Sharp F. R. (1996): Global ischemia induces apoptosis-associated genes in hippocampus. Brain Res. Mol. Brain Res. 42, 79-88; doi:10.1016/S0169-328X(96)00121-0

Hossmann K. A., Paschen W. (1992): Disturbances of protein and polyamine metabolism after reversible cerebral ischemia. In: Neurochemical Correlates of Cerebral Ischemia. (Eds. N. G. Bazan, P. Braquet and M. D. Ginsberg), pp. 59-83, Plenum Press, New York

Hrehorovská M., Burda J., Domoráková I., Mechírová E. (2004): Effect of tanakan on postischemic activity of protein synthesis machinery in the rat brain. Gen. Physiol. Biophys. 23, 457-465

Kato H., Kogure K., Nakata N., Araki T., Itoyama Y. (1995): Facilitated recovery from postischemic suppression of protein synthesis in the gerbil brain with ischemic tolerance. Brain Res. Bull. 36, 205-208; doi:10.1016/0361-9230(94)00191-3

Kleihues P., Hossmann K. A., Pegg A., Kobayashi K., Zimmerman V. (1975): Resuscitation of the monkey brain after one hour complete ischemia. Brain Res. 95, 61-73; doi:10.1016/0006-8993(75)90207-3

Kogure K., Kato H. (1993): Altered gene expression in cerebral ischemia. Stroke 24, 2121-2127

Koudelova J., Mourek J., Drahota Z., Rauchova H. (1994): Protective effect of carnitine on lipoperoxide formation in rat brain. Physiol. Res. 43, 387-389

Kumar R., Azam S., Sullivan J. M., Owen C., Cavener D. R., Zhang P., Ron D., Harding H. P., Chen J. J., Han A., White B. C., Krause G. S., DeGracia D. J. (2001): Brain ischemia and reperfusion activates the eukaryotic initiation factor $2 \alpha$ kinase, PERK. J. Neurochem. 77, 1418-1421; doi:10.1046/ j.1471-4159.2001.00387.x
Kumar R., Krause G. S., Yoshida H., Mori K., DeGracia D. J. (2003): Dysfunction of the unfolded protein response during global brain ischemia and reperfusion. J. Cereb. Blood Flow Metab. 23, 462-471; doi:10.1097/00004647200304000-00010

Kuzin B. M., Kolesnikova T. I. (1999): The neurotropic effect of aplegin (carnitine) in cerebral hypoxia. Zh. Nevrol. Psikhiatr. Im. S. S. Korsakova 99, 27-32 (in Russian)

Limketkai B. N., Zucker S. D. (2008): Hyperammonemic encephalopathy caused by carnitine deficiency. J. Gen. Intern. Med. 23, 210-213; doi:10.1007/s11606-007-0473-0

Lipton P. (1999): Ischemic cell death in brain neurons. Physiol. Rev. 79, 1431-1568

Martin de la Vega C., Burda J., Salinas M. (2001): Ischemia-induced inhibition of the initiation factor $2 \alpha$ phosphatase activity in the rat brain. Neuroreport 12, 1021-1025; doi:10.1097/00001756-200104170-00031

Matsuoka M., Igisu H. (1992): Preservation of energy metabolites by carnitine in the mouse brain under ischemia. Brain Res. 590, 334-336; doi:10.1016/0006-8993(92)91117-W

Minana M. D., Hermenegildo C., Llsansola M., Montoliu C., Grisolia S., Felipo V. (1996): Carnitine and choline derivatives containing a trimethylamine group prevent ammonia toxicity in mice and glutamate toxicity in primary cultures of neurons. J. Pharmacol. Exp. Ther. 279, 194-199

Neumar R. W., DeGracia D. J., White B. C., McDermott P. J., Evans D. R., Krause G. S. (1995): Eukaryotic initiation factor $4 \mathrm{E}$ degradation during brain ischemia. J. Neurochem. 65, 1391-1394

Neumar R. W., Hagle S. M., DeGracia D. J., Krause G. S., White B. C. (1996): Brain mu-calpain autolysis during global cerebral ischemia. J. Neurochem. 66, 421-424

Neumar R. W., DeGracia D. J., Konkoly L. L., Khoury J. I., White B. C., Krause G. S. (1998): Calpain mediates eukaryotic initiation factor $4 \mathrm{G}$ degradation during global brain ischemia. J. Cereb. Blood Flow Metab. 18, 876-881; doi:10.1097/00004647-199808000-00007

Pulsinelli W. A., Brierley J. B. (1979): A new model of bilateral hemispheric ischemia in the unanesthetized rat. Stroke 10, 267-272

Schmidt-Kastner R., Paschen W., Ophoff B. G., Hossmann K. A. (1989): A modified four-vessel occlusion model for inducing incomplete forebrain ischemia in rats. Stroke 20, 938-946

Thilmann R., Xie Y., Kleihues P., Kiessling M. (1986): Persistent inhibition of protein synthesis precedes delayed neuronal death in postischemic gerbil hippocampus. Acta Neuropathol. 71, 88-93; doi:10.1007/BF00687967

Thilmann R., Xie Y., Kleihues P., Kiessling M. (1988): Delayed ischemic cell death in gerbil hippocampus: suppression and recovery of protein synthesis and the protective effect of cycloheximide. Clin. Neurol. 5, 107

Tsakiris T., Angelogianni P., Tesseromatis C., Tsakiris S., Schulpis K. H. (2008): Effect of L-carnitine administration on the modulated rat brain protein concentration, acetylcholinesterase, $\mathrm{Na}^{+}, \mathrm{K}^{+}$-ATPase and $\mathrm{Mg}^{2+}$-ATPase activities induced by forced swimming. Br. J. Sports Med. 42, 367-372; doi:10.1136/bjsm.2007.039792 
Tunez I., Munoz M. C., Medina F. J., Salcedo M., Feijoo M., Montilla P. (2007): Comparison of melatonin, vitamin $\mathrm{E}$ and $\mathrm{L}$-carnitine in the treatment of neuro- and hepatotoxicity induced by thioacetamide. Cell Biochem. Funct. 25, 119-127; doi:10.1002/cbf.1276

Wang C., Sadovova N., Ali H. K., Duhart H. M., Fu X., Zou X., Patterson T. A., Binienda Z. K., Virmani A., Paule M. G., Slikker W. Jr., Ali S. F. (2007): L-carnitine protects neurons from 1-methyl-4-phenylpyridinium-induced neuronal apoptosis in rat forebrain culture. Neuroscience 144, 46-55; doi:10.1016/j.neuroscience.200 6.08 .083

White B. C., Sullivan J. M., DeGracia D. J., O’Neil B. J., Neumar R. W., Grossman L. I., Rafals J. A., Krause G. S. (2000): Brain ischemia and reperfusion: molecular mechanisms of neuronal injury. J. Neurol. Sci. 179, 1-33; doi:10.1016/ S0022-510X(00)00386-5

Widmann R., Kuroiwa T., Bonnekoh P., Hossmann K. A. (1991): $\left[{ }^{14} \mathrm{C}\right]$ leucine incorporation into brain proteins in gerbils after transient ischemia: relationship to selective vulner- ability of hippocampus. J. Neurochem. 56, 789-796; doi:10.1111/j.1471-4159.1991.tb01993.x

Yakubov E., Gottlieb M., Gil S., Dinerman P., Fuchs P., Yavin E. (2004): Overexpression of genes in the CA1 hippocampus region of adult rat following episodes of global ischemia. Brain Res. Mol. Brain Res. 127, 10-26; doi:10.1016/ j.molbrainres.2004.05.010

Zalewska T., Zablocka B., Saido T. C., Zajac H., Domanska-Janik K. (1998): Dual response of calpain to rat brain postdecapitative ischemia. Mol. Chem. Neuropathol. 33, 185-197; doi:10.1007/BF02815181

Zou X., Sadovova N., Patterson T. A., Divine R. L., Hotchkiss C. E., Ali S. F., Hanig J. P., Paule M. G., Slikker W. Jr., Wang C. (2008): The effects of L-carnitine on the combination of, inhalation anesthetic-induced developmental, neuronal apoptosis in the rat frontal cortex. Neuroscience 151, 1053-1065; doi:10.1016/j.neuroscience.2007.12.013

Received: November 3, 2008

Final version accepted: March 5, 2009 